It may also be of interest to state that on the 2 Ist inst. I observed a bright meteor to shoot in a path from near the Pole Star to Capella, vanishing near the latter after discharging a trilliant light-green flash.

From Ilfracombe the view to the north commands an extensive range of the sea horizon.

$$
\text { ERAS. OMMANney, Rear-Admiral }
$$

Ilfracombe, Devon

\section{Natural History Museums}

WHILE admiring and agreeing with the main features of Dr P. L. Sclater's plan for the exhibition of the National Natural Histury collections in the new Museum at Kensington, I must beg to be allowed to enter a protest with regard to the geological portion of the scheme, which was all but completely overlooked by those who took part in the discussion of his suggestions and by Dr. Sclater himself.

The only words which Dr. Sclater devoted to the subject were to the effect that the palrontological collections should be merged into the general zoological and botanical ones. This arrangement is, however, one which will not serve the purpose of the geologist. We can fancy the utter misery of the man who wishes to study the fossils of some special formation, when he finds that to do so he will have to rush from case to case, amid stuffed and spirit specimens of all kinds, all over the place. The naturalists who deplore the loss of time incurred by them under the present order of things at the British Museum, have no thought for the geologist whom their proposed arrangement would condemn to far worse wandering in the new building. But in this particular I, as a geologist, sincerely trust that the project will not be carried out without some revision, and that a palaontological collection, quite independent of any other, and arranged stratigraphically, will form a by no means inconspicuous part of the Museum. The advantages of this. system may be seen at a glance in Jermyn Street, where the British fossils are thus arranged.

In a collection as large as that of the Nationil Museum. must be, it may very likely be found impossible to exhibit specimens of every species in the show cases, and indeed it is by no means desirable that this should be done. It would be quite sufficient, and as far as the general public is concerned infinitely better, to limit the exhibited specimens to those belonging to species characteristic of each formation, and to keep all others, which would interest students only, in a cabinet drawer, where they would be at once handy to the specialist and not wearying to the sight-seer. I uplicates enough could doubtless be spared to complete the zoological and botanical series in the lower galleries, but unique and rare specimens should, to my mind, most decidedly be kept for the geological series. In conjunction with the latter, it would be highly desirable to establish a lithological collection, the absence of which, with the solitary exception of the small one in the Geological Museum, is every day more and more to be wondered at in such a country as curs.

Not only should appropilate rock-specimens accompany the fossils of each fossiliferous bed, but they should be so axranged that the organisms and the matrix in which they are found em bedded, could be examined side by side. Typical examples of unfossiliferous strata should be placed in their regular order of succession, including specimens of contemporaneous rocks from other parts of the world. Clear geological sketch-maps, boldly coloured and not over-burdened with names, showing the distribution (so far as it is known) of the various equivalent groups of beds, should be placed in conspicuous places at intervals in the room or gallery, and thus, or in some closely-resembling manner, could a homogeneous whole be arrived at, combining the greates amount of instruction to the public and the greatest convenience to the student

Of course the geological collection shadowed forth above would by no means take the place of another more detailed lithological collection, which should, ir possible, be added to the mineralogical one, containing all the igneous rocks, \&c., and, like the ninerals, arranged chemicallv.

G. A. LEBOUR, F.G.S. \& of the Geological Survey of England.

\section{Changes of Level at Pozzuoli, referred to in the}

\section{"Apocryphal Acts of Peter and Paul"}

IN the well-known description which Sir Charles Lyell gives of the changes of level of the shores of the Bay of Baize in tle 3oth chapter of his "Principles of Geology," there occur at pagis $172-174$ (vol ii, Ioth edition) the following statements.
Speaking of the so-called "Temple of Serapis," and its adornment by the Emperor Alexander Severus between A.D. 222 and 235, he says: "From that era there is an entire dearth of historical information for a period of 12 centuries, except the significant fact that Alaric and his Goths sacked Pozzuoli in 410 , and that Genseric did the like in 440 A. D." Again : "The period of deep 3ubmergence was certainly antecedent to the close of the 15 th century" - a statement which he goes on to prove by a quotation from Loffiedo referring to the year 1530 , and $a$, reference to documents cited by A. di Joris, one of which, dated 1503 , speaks of land "where the sea is drying up."

Still more recently Professox: Phillips, in his interesting volume on Vesuvius, speaking (p. 244) of the "Temple of Serapis," observes that, at the time of its adomment by the Emperor, " early in the 31 d century, it must have been in its original, or else in its second stage-perhaps we may adopt the latter view-there may have been a depression of $5 \mathrm{ft}$., a new floor, restoration, and adornment. Nothing is absolutely known of any further change of level till the early part of the 16th century."

Thus both the authorities cited appear to agree that from the middle of the 3 rd to the end of the isth century there is a total absence of information. You may therefore possibly think that the following extract from the "Apocryphal Acts of Peter and Paul " possesses some interest, even though it may be difficult to agree on the approximate date of the writer. Your columns would scarcely be the place, nor am I competent, to discuss this last point, but as one of the MSS. collected by Professor Tischendorf for his edition of the Greek orisinal is said to be of the end of the gth century, it appears to me that we have here not only a rather quaint explanation of the immediate cause of the changes of level of the land at Pozzuoli and in its neighbourhood, but a distinct reference at lectst to six centuries before the Italian writers already quoted, not merely to the fact, but also to the extent, of the movement. in question. Notwithstanding its suspicious legendary framework, the statement that "Pontiole sunk into the sea-shore about one fathom; and there it is until this day, for a remembrance, under the sea," has an air of vraisemblance, a ring of truthfulness, about it which I hope will justify my bringing the matter under the notice of those so much more competent than $I$ am to assign to it its true value, and to whom it may possibly be new.

I quote from the translation by $\mathrm{Mr}$. A. Walker, forming a portion of Vol. xvi. of the "Ante-Nicene Library," published by Messrs. Clark of Edinburgh, pp. 257-8.

Frenchay, near Bristol, Oct. 3

F. Fox Tucketr

"And when Paul came out of Mesina he sailed to Didymus, and remained there one night; and having sailed thence, he came to Pontiole (Puteoli) on the second day. And Dioscorus the shipmaster, who brought him to Syracuse, sympathising with Paul becruse he had delivered his son from death, having left his own ship in Syracuse, accompanied him to Pontiole. And some of Peter's disciples having been found there, and having received Paul, exhorted him to stay with them. And he stayed a week in hiding, because of the command of Cresar (that he should be put to death). And all the toparchs were watching to seize and kill him. But Dioscorts the shipmaster, being himself bald, wearing his shipmaster's dress, and speaking boldly, on the first clay went into the city of Pontiole. Thinking, therefore, that he was Paul, they seized him and beheaded him, and sent his head to Cresar.

"And Paul, being in Pontiole, and having heard that Dioscorus had been beheaded, being grieved with great grief, gazing into the height of the heaven, said: 'O Lord Almighty in Heaven, who has appeared to me in every place whither I have gone on account of 'thine only begotten Word, our Lord Jesus Christ, punish this city, and bring out all who have believed in God and followed His Word.' He said to them, therefore, 'Follow me. And going forth from Pontiole with those who had believed in the Word of God, they came to a place called Baias (Baire), and looking up with their eyes, they all see that city called Pontiole sink into the sea-shore about one fathom, and there it is until this day', for a remembrance, under the sea.

"And those who had been saved out of the city of Pontiole, that had been swallowed up, reported to Cresar in Rome that Pontiole had been swallowed up with all its multitude."

\section{Hèreditary Deformities}

IN the number of NATURE for Sept. 3, a letter from Mr. William Field appears with the title "Hereditary Deformities," 